\title{
39. LATE PLEISTOCENE TEPHROCHRONOLOGY OF PIGMY BASIN, DEEP SEA DRILLING PROJECT SITE 619, LEG 96 $^{1}$
}

\author{
Michael T. Ledbetter, Moss Landing Marine Laboratories²
}

\begin{abstract}
The hydraulic piston cores from Site 619 in the Pigmy Basin were sampled for dispersed tephra zones. The sampling interval employed revealed only minor amounts of dispersed tephra; however, one ash layer was analyzed for major-element chemistry in order to correlate the tephrochronology of Site 619 and the late Pleistocene Gulf of Mexico. The ash layer in Sample 619-16,CC (142 m sub-bottom depth) is correlated with the Y8 ash that was erupted from the Lake Atitlan Caldera, Guatemala 84,000 yr. ago (approximately coinciding with the oxygen-isotope Stage $5 \mathrm{a} / 5 \mathrm{~b}$ boundary). Dispersed tephra at approximately 119 and $150 \mathrm{~m}$ can be correlated with the Y6 (65,000 yr.) and X2 (110,000 yr.) ash layers, respectively, based on position within the oxygen-isotope stratigraphy. The tephrochronology at Site 619 provides a chronologic horizon for correlation of other stratigraphic results with the time scale.
\end{abstract}

\section{INTRODUCTION}

The late Pleistocene section of the western Gulf of Mexico contains tephra horizons that are suitable for stratigraphic correlation (Kennett and Huddlestun, 1972; Thunell, 1976; Ledbetter, 1984, 1985). The ash layers were originally correlated and named by their position within the foraminiferal biostratigraphic zonation of Ericson and Wollin (1968), as subdivided by Kennett and Huddlestun (1972). Conspicuous tephra horizons were noted in Subzones X2-X5, Y6, Y8, and W1 (Kennett and Huddlestun, 1972; Thunell, 1976). Because biostratigraphy was used to identify each tephra horizon, however, the utility of tephrochronology as a stratigraphic tool in its own right was not fully realized.

The most widespread late Pleistocene tephra in the Central American region is the Y8 ash in the Gulf of Mexico, which is correlated with the Worzel Layer D (Bowles et al., 1973) in the eastern Pacific and the Los Chocoyos Ash from Lake Atitlan Caldera, Guatemala (Drexler et al., 1980). These Y8 ash correlations were accomplished using the major- and minor-element chemistry of glass shards (Drexler et al., 1980), rather than correlation with biostratigraphic zonations, thus representing full utilization of the tephra horizons for chronostratigraphy. The major-element chemistry of an additional five tephra horizons in the western Gulf of Mexico was established by Rabek et al. (1985). The age of all six tephra was determined by position within an oxygen-isotope stratigraphy and provides an unambiguous chronostratigraphy for the region for the past 185,000 yr. (Rabek et al., 1985).

The major-element chemistry of a volcanic ash layer recovered at Site 619 (Fig. 1) in the Pigmy Basin correlated with the late Pleistocene tephrochronology of the Gulf of Mexico (Fig. 2). This ash layer at Site 619 provides a distinct chronostratigraphic horizon for correla-

\footnotetext{
${ }^{1}$ Bouma, A. H., Coleman, J. M., Meyer, A. W., et al., Init. Repts. DSDP, 96: Washington (U.S. Govt. Printing Office).

2 Address: Moss Landing Marine Laboratories, P.O. Box 450, Moss Landing, CA 95039.
}

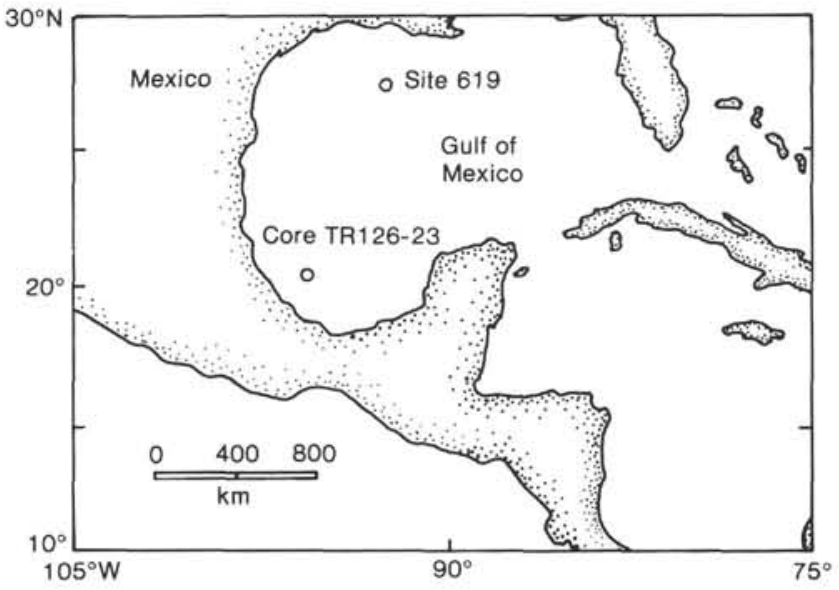

Figure 1. Location of DSDP Site 619 (Pigmy Basin) and piston Core TR126-23.

tion of other stratigraphic parameters (e.g., Williams and Kohl, this volume) with the time scale.

\section{METHODS}

The $>38-\mu \mathrm{m}$ fraction of $10-\mathrm{cm}^{3}$ samples from cores recovered at Site 619 was examined under a binocular microscope to identify semiquantitatively the relative concentration of volcanic glass shards (Fig. 3). Glass shards from one ash layer (Sample 619-16,CC) were separated, mounted in plastic disks with epoxy, ground, polished, and carbon coated for electron-microprobe analysis. Details of the analytical techniques are found in Rabek et al. (1985). The tephra was analyzed for the eight major elements, which were expressed as oxide percentages and renormalized to $100 \%$ (Table 1).

\section{DISCUSSION}

The tephrochronology of the western Gulf of Mexico provides a means for correlating specific horizons containing dispersed tephra or volcanic ash layers in Site 619 (Fig. 3) with the time-scale. This correlation requires that an ash layer possess a unique chemistry before an age can be assigned. The major-element chemistry of one ash layer located in Sample 619-16,CC (Fig. 3) was compared with the chemistry of six tephra in piston Core 




Figure 2. Late Pleistocene tephrochronology of the Gulf of Mexico piston Core TR126-23 from Rabek et al. (1985). The ages of megascopic ash layers (solid pattern) Y8 (84,000 yr. ago), X2 (110,000 yr. ago), and W1 (136,000 yr. ago) are based on the position of each layer within the oxygen-isotope stratigraphy of the core. The ages of ash layers Y5 (30,000 yr. ago), Y6 (65,000 yr. ago), and W2 $(185,000$ yr. ago), were determined by the position of dispersed tephra zones (hatched pattern). Location of piston Core TR126-23 shown in Figure 1.

TR126-23, from the western Gulf of Mexico, for which both a chemistry (Table 1) and an age (Fig. 2) were identified by Rabek et al. (1985). The ash layer is correlated unambiguously with the Y8 ash (Fig. 2) based on majorelement chemistry (Table 1; Fig. 4). Therefore, the ash layer in Sample 619-16,CC (142 m sub-bottom depth) is $84,000 \mathrm{yr}$. old and approximately correlates with the oxygen-isotope Stage $5 \mathrm{a} / 5 \mathrm{~b}$ boundary based on the previous tephrochronology (Fig. 2). Oxygen-isotope analyses of Core 619-16 reveal, however, that the Y8 ash layer falls slightly above the Stage $5 \mathrm{a} / 5 \mathrm{~b}$ boundary in this higher resolution oxygen-isotope record (Williams and Kohl, this volume).

In addition to the tephra layer in Sample 619-16,CC, dispersed tephra horizons were identified throughout the hole. Dispersed ash in Core 619-16 is assumed to be the result of bioturbation of the layer in Sample 619-16,CC. The dispersed tephra in Samples 619-14-2, 30-33 cm ( $\sim 119 \mathrm{~m}$ sub-bottom depth) and 619-17-3, 122-126 cm ( $\sim 150 \mathrm{~m}$ sub-bottom depth) are assigned ages of 65,000 and $110,000 \mathrm{yr}$., respectively. The age assignments are based on the position of those tephra within the oxygenisotope stratigraphy of Site 619 (Williams and Kohl, this volume) and the position of the Y6 and X2 tephra in Figure 2. Unfortunately, too few glass shards were recovered for a statistically significant chemical analysis. Dispersed tephra horizons at $\sim 168$ and $176 \mathrm{~m}$ sub-bottom depth were not analyzed because the zone from 156 to $184 \mathrm{~m}$ is a debris flow (Kohl, this volume) and is of little stratigraphic use. The very rare occurrences of tephra in Cores $619-4,-5,-13$, and -18 (Fig. 3) could not be correlated with the Gulf of Mexico tephrochronology.

The tephrochronology of the Site 619 ashes is consistent with the foraminiferal biostratigraphy (Kohl, this volume) and oxygen-isotope stratigraphy (Williams and Kohl, this volume). The Y6 ash in Site 619 falls within oxygen-isotope Stage 4, the Y8 ash below the Stage 4/5 boundary, and the X2 ash deeper within Stage 5 (Williams and Kohl, this volume). Therefore, the stratigraphic position of each ash layer at Site 619 is consistent with the occurrence in piston Core TR126-23 (Fig. 2), which was used to establish the late Pleistocene Gulf of Mexico tephrochronology (Rabek et al., 1985).

The tephrochronology of ashes at Site 619, therefore, provides a distinct chronostratigraphy for three horizons in the hole. Those horizons may be used to correlate other stratigraphic results with the time scale.

\section{ACKNOWLEDGMENTS}

I thank B. Kohl and D. Williams for sharing samples and providing preliminary data. This manuscript was reviewed by S. Self and W. Rose. A. Klaus and J. Muller are thanked for their diligent laboratory work. Microprobe analysis was provided by K. Rabek. This research was supported by NSF Grant OCE-8315152.

\section{REFERENCES}

Bowles, F. A., Jack, R. N., and Carmichael, I. S. E., 1973. Investigation of deep-sea volcacanic ash layers from equatorial Pacific cores. Geol. Soc. Am. Bull., 84:2371-2388.

Drexler, J. W., Rose, W. I., Jr., Sparks, R. S. J., and Ledbetter, M. T., 1980. The Los Chocoyos Ash, Guatemala: a major stratigraphic marker in Middle America and in three ocean basins. Quat. Res., 13:327-345.

Ericson, D. B., and Wollin, G., 1968. Pleistocene climates and chronology in deep-sea sediments. Science, 162:1227-1234.

Kennett, J. P., and Huddlestun, P., 1972. Late Pleistocene paleoclimatology, foraminiferal biostratigraphy and tephra chronology, western Gulf of Mexico. Quat. Res., 2:38-69.

Ledbetter, M. T., 1984. Late Pleistocene tephrochronology in the Gulf of Mexico region. In Healy-Williams, N. (Ed.), Principles of Pleistocene Stratigraphy Applied to the Gulf of Mexico: Boston (IHRDC Press), pp. 119-148

, 1985. Tephrochronology of marine tephra adjacent to Central America. Geol. Soc. Am. Bull., 96:77-82.

Rabek, K., Ledbetter, M. T., and Williams, D. F., 1985. Tephrochronology of western Gulf of Mexico for the last 185,000 years. Quat. Res. 23:403-416.

Thunell, R. C., 1976. Calcium carbonate dissolution history in Late Quaternary deep-sea sediments, western Gulf of Mexico. Quat. Res, 6:281-297.

Date of Initial Receipt: 4 February 1985

Date of Acceptance: 11 March 1985 


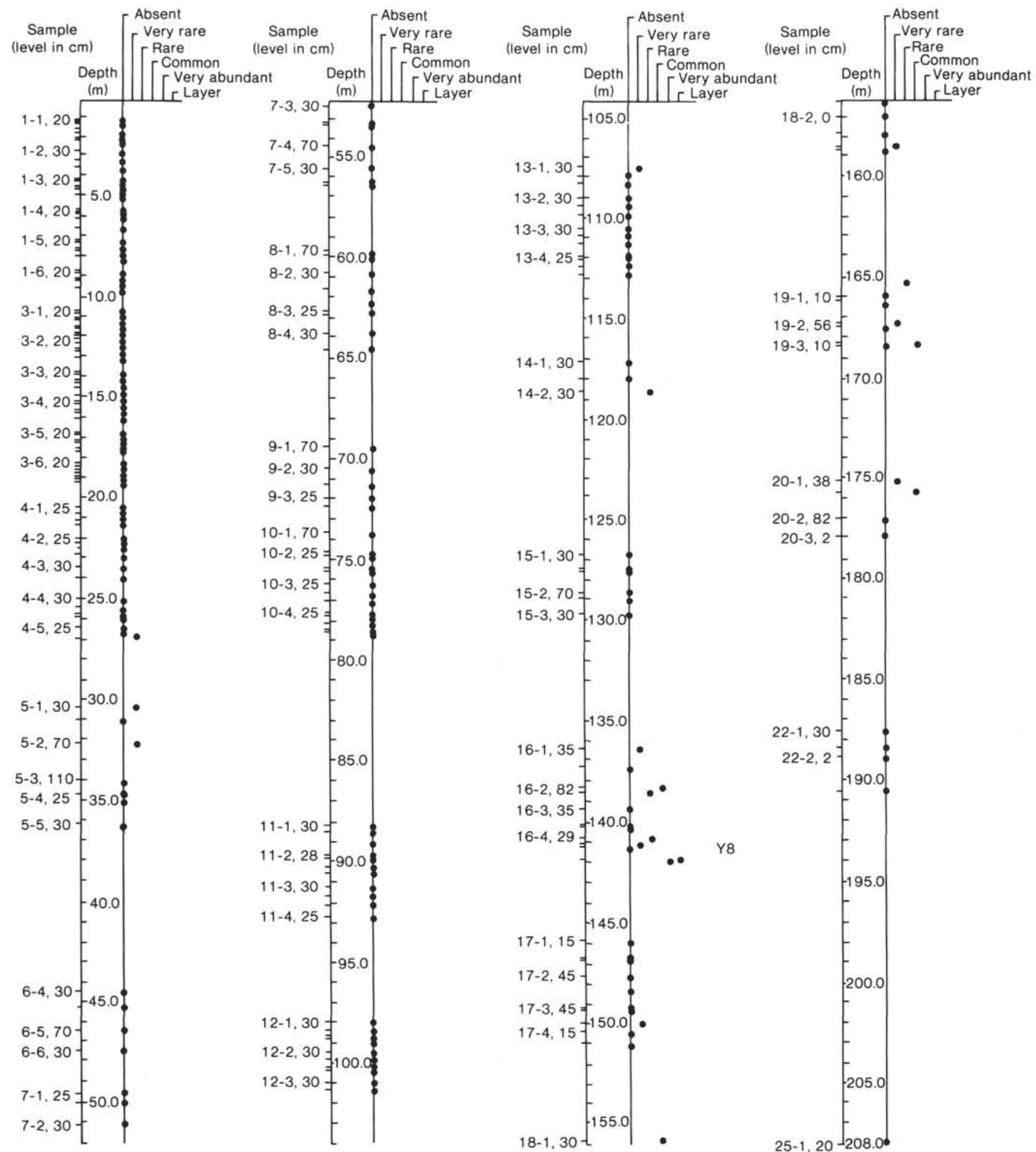

Figure 3. Relative concentration of tephra in the $>38-\mu \mathrm{m}$ fraction is qualitatively divided into five categories for dispersed tephra and megascopic layer. Only the first sample in each section is numbered. The Y8 ash located in Sample 619-16,CC was correlated with the Gulf of Mexico tephrochronology (see Fig. 2 and Table 1) and an age was assigned. 
Table 1. Average major-element chemistry of six late Pleistocene tephra from the Gulf of Mexico (Rabek et al., 1985) and one tephra layer from Site 619.

\begin{tabular}{lrrrrrrr}
\hline \multicolumn{1}{c}{ Oxide } & \multicolumn{1}{c}{ Y5 } & \multicolumn{1}{c}{ Y6 } & \multicolumn{1}{c}{ Y8 } & X2 & W1 & W2 & $\begin{array}{c}\text { Sample } \\
619-16, C C\end{array}$ \\
\hline $\mathrm{SiO}_{2}(\%)$ & 76.53 & 74.28 & 77.80 & 73.74 & 77.48 & 76.54 & 77.14 \\
$\mathrm{TiO}_{2}$ & 0.06 & 0.34 & 0.18 & 0.36 & 0.11 & 0.12 & 0.21 \\
$\mathrm{Al}_{2} \mathrm{O}_{3}$ & 13.93 & 14.22 & 12.95 & 14.05 & 12.54 & 12.57 & 12.87 \\
$\mathrm{FeO}$ & 0.74 & 1.58 & 0.67 & 1.51 & 0.85 & 1.22 & 0.65 \\
$\mathrm{MgO}$ & 0.15 & 0.38 & 0.36 & 0.31 & 0.31 & 0.19 & 0.21 \\
$\mathrm{CaO}$ & 0.56 & 1.08 & 0.88 & 0.95 & 0.51 & 0.53 & 0.82 \\
$\mathrm{Na}{ }_{2} \mathrm{O}$ & 3.71 & 3.64 & 3.34 & 4.36 & 3.70 & 4.08 & 4.05 \\
$\mathrm{~K}_{2} \mathrm{O}$ & 4.32 & 4.48 & 3.98 & 4.72 & 4.50 & 4.76 & 4.05 \\
\hline
\end{tabular}

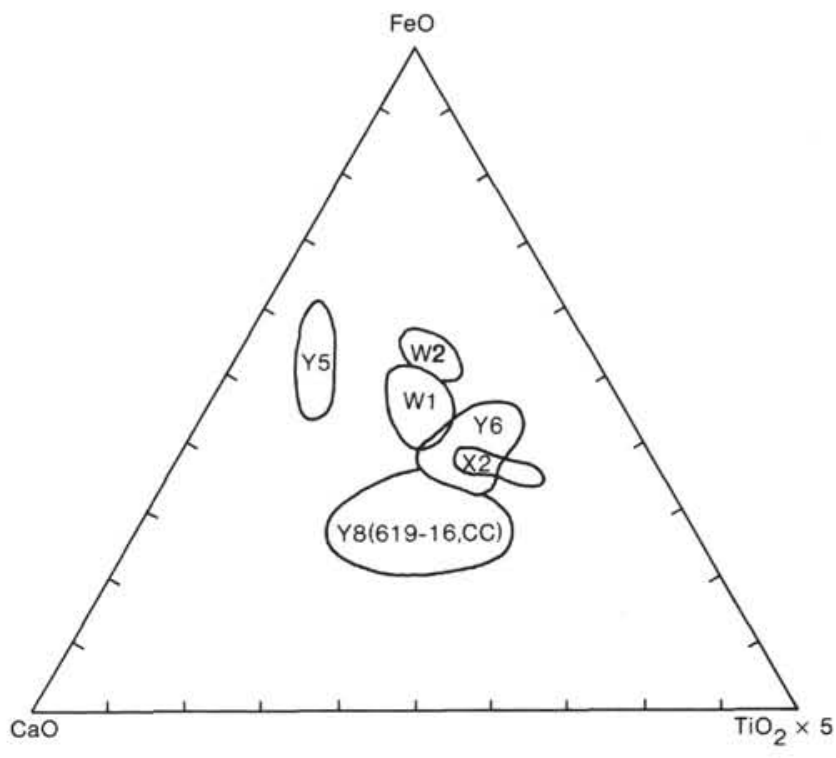

Figure 4. Ternary plot of $\mathrm{CaO}-\mathrm{FeO}-\mathrm{TiO}_{2} \times 5$ used to demonstrate the chemical correlation of the ash layer located in Sample 619-16,CC (Fig. 3) with six tephra in the western Gulf of Mexico (Fig. 2; Rabek et al., 1985). The oxide percentages of other elements (Table 1) were also used to confirm the correlation. 